International Journal of Social and Administrative Sciences

$\operatorname{ISSN}(e): 2521-0556$

DOI: $10.18488 /$ journal.136.2021.62.55.69

Vol. 6, No. 2, 55-69.

(C) 2021 AESS Publications. All Rights Reserved.

URL: www.aessweb.com

check for
updates

\title{
DETERMINANTS OF CONTRACT FARMING ADOPTION AND ITS IMPACT ON PRODUCTIVITY OF SMALLHOLDER COTTON PRODUCERS IN TANZANIA
}

iD Paul Maganga Nsimbila

\author{
Department of Procurement and Logistics Management School of Business \\ Mzumbe University Mzumbe, Morogoro, Tanzania. \\ Email:pmnsimbila@mzumbe.ac.tz
}
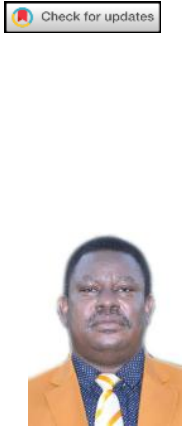

Article History

Received: 4 March 2021 Revised: 8 April 2021 Accepted: 12 May 2021 Published: 1 June 2021

\section{Keywords}

Contract farming

Ginners

Adoption

Contract farmers

Non-contract farmers

Productivity.

\section{ABSTRACT}

The focus of this paper was on the determinants of contract farming adoption and its impact on productivity to smallholder cotton producers in Bunda District, Tanzania. A survey of 220 contract farmers and 194 non-contract farmers was done by the researcher through personally administered questionnaires. Results from the treatment effects model show that gender of household head, household head age, experience in cotton cultivation, obtaining loan from other sources, being wage-earner, owning cattle, and owning bicycle had influence on adopting contract farming. However, education of household head, household size, off farm activities, owning motorcycle and radio had no influence on adopting contract farming. With regard to impact of contract farming adoption to productivity of smallholder cotton farmers in the investigation region, findings show that there is insignificant impact due to late supply of inputs to farmers by ginners, sprayers were not given on loan basis to farmers for spraying their farms in order to control pests and cultivation service was provided at TShs. 30,000/= upfront which was not afforded by farmers. In this case, Tanzania Cotton Board (TCB) should launch major campaign to educate farmers and ginners on the advantages of contract farming, secondly, ginners should be instructed to supply inputs (cotton seed and pesticides) to farmers timely and lastly ginners should provide sprayers and cultivation services to farmers as agreed when signing contract. Otherwise, contract farming adoption for the purpose of increasing productivity will be a nightmare.

Contribution/ Originality: This study contributes rigorously on the qualitative and quantitative analysis on the action taken by the farmers on the contract farming participation and its impact on seed cotton production. The study offers an insight for understanding the determinants of contract farming and its impact on seed cotton production in Tanzania.

\section{INTRODUCTION}

Agriculture is the most important area in the economic sector of Tanzania and presents around $50 \%$ of both export earnings and GDP. Beyond $80 \%$ of the deprived people are in rural communities and needs of their income is unable to manage without agriculture. Furthermore, $80 \%$ of the general public is located at the rural areas and they earn their livings through agriculture as the essential pillar of their life (ASDS, 2001; URT, 2016). Over the last decade agriculture sector upheld a sustainable growth rate of above $3 \%$ annually. Despite of the fact that this rate is exceeding the population growth rate, it is deemed to have been poor due to its failure to enhance the rural people 
livelihood whereas these people rely on agriculture as their main occupation. This comprises localized lack of food as well as hunger that remained to be affected by poor access to as well as insufficient facilities endowments at the household's level (ASDS, 2001; URT, 2016).

While the economy of Tanzania is led by Agricultural Sector, Cotton is considered to be among the largest export agricultural product as it is the second largest export agricultural product count for more than $70-80 \%$ of its harvests are exported. Most cotton growers are smallholder farmers who possess between $1 / 2$ and 10 acres of cotton crops and generally cultivate in rain fed agricultural areas. According to the Tanzania Cotton Board (CSDSII, 2010; TCB , 2010) in three years Cotton production has tripled from 44,000 tons in the season of 2006-2007 to 124,000 tons in the season of 2008-2009 as a result of stable supply of agricultural inputs. However, to date, seed cotton production is still not stable and varies from time to time according to the weather conditions (droughts) and the international market price volatility (TCB, 2018). Preliminary examination by Rural Livelihood Development Company -RLDC (2008) and BoT (2016) of the cotton value-chain revealed that numerous restrictions needed to be tackled so as to improve subsectors' productivity. Examples include: producers' access to agricultural inputs as well as services, low prices volatility in domestic and global markets, environments of competitive business, powerful farmers organization groups, access to credit and ginning facilities. Contract Farming (CF) is thought to unlock these constraints.

Contract farming relates to an energetic upright-coordination existing between producers of an agricultural commodity and customers or processing industries of that commodity. Globally, CF work had begun for the purpose of solving the low-productivity problem, has been introduced in order to solve the problem of low productivity, input power source, access to market as well as income to small-holder farmers. Normally, it comprises a big agri-business company engaging into commercial contracts with small-holder farmers (either individually or in groups), or big business farmers, to offer production inputs on the basis of loan and extension services to the growers in exchange for a promised shipment of produce. CF could also be regarded as a kind of a governance of business operations that emerge in reaction to input failures, loans, insurance, as well as product markets (Key \& Runsten, 1999; Prowse, 2012).

Nationally, a growth of productivity advances standards of living due to the fact that too real revenue enhance people's purchasing power, relaxation, home improvements and education as well as support to social, economic and environmental programs. It is important to the firm to have a productivity growth as it can provide assurance of fulfilling its implementation of the commitments to its suppliers, customers, employees, stockholders, and governments (taxation and regulations), and always improve its competitiveness and/or stay competitive commercially (Yadav \& Marwah, 2015). Additionally, increasing productivity is essential for the improvement of small-holder farmers' livelihood, which is the major part of the rural poor-population in Tanzania. Msuya, Hisano, and Nariu (2008) and Rapsomanikis (2015) show that, low level of productivity is one of the basic reasons of poor and ever-changing value-added along the value chains which leads to a static economy in rural areas with continuance of privation. Therefore, improved productivity of cotton is significant for the well-being of livelihoods of small-holder farmers within the nation.

As reported by NEPAD (2006) and Prowse (2012) the total yield (100\%) of tobacco and cotton in Mozambique, $90 \%$ of cotton production in Malawi, as well as $70 \%$ of the same in Zimbabwe, are produced by the means of contract farming. However, $100 \%$ of tobacco and paprika cotton in Zambia are produced by using this method. On the other hand, in Kenya, farmers who engaged in contract farming bring under cultivation $60 \%$ of sugar and tea, also all tobacco of the country. In Kenya, for beyond $1 \frac{1}{2}$ decades, the prosperous horticultural as well as flower export professionals have been basically relying on contract farming with the involvement of both large commercial and smallholders farmers jointly with the changing proportions in their production approaches year after year (Dolan \& Humphrey, 2000; Hall, Scoones, \& Tsikata, 2017; Harris, 1992). Contract farming is widely used in South Africa, and it is therefore used for various commodities. However, contract farming in South Africa is 
being increasingly sophisticated in comparison with contracts in elsewhere of the region (Abdullah \& Sulaiman, 2013; Vermeulen, Kirsten, \& Sartorius, 2006).

Songsak and Wiboonpoongse (2008) and Azman, D'Silva, Samah, Man, and Shaffril (2013) argue that assistance from agricultural processing industries in improvement of productivity growth and quality was essential. A new variety of soybean from the frozen food firm was boosted production from 80okg/rai in 1991 - 1992 up to $1,300-1,700 \mathrm{~kg} / \mathrm{rai}$ in 1993 . A contract system may improve production efficiency of farmers. Wongwiwat et al., (2007) cited in Songsak and Wiboonpoongse (2008) stated in their study that Chiang Mai growers could have increased potato production by $43 \%$ when compared with yields of non-contract growers. The knowledge succeeded by education is a predominant attribute of effectiveness, whereas diseconomies of scale were noted for the size of potato production increasing above 1.4 acres.

According to Marenya and Barrett (2007) and Mango, Makate, Tamene, Mponela, and Ndengu (2018) the farm size in the possession of household, its livestock value, non-agricultural revenue, family supply of labor, as well as gender of the household head and attainment of educational together had a very favorably impact probability of compliance with better management of natural resources. Feder, Just, and Zilberman (1985) and Diiro and Sam (2015) introduced elements that, in theory, would influence adoption of latest farm-technologies which involve the credit availability. These include availability of credit, risk aversion, farm tenure arrangements, limited access to information, inadequate incentives, inadequate farm size, unreliable and insufficient supply of complementary inputs as well as labor constraints.

Furthermore, Mazvimavi and Twomlow (2009) and Haneishi, Maruyama, Takagaki, and Kikuchi (2014) discovered behavioral risk, institutionalized contacts, as well as size of the farm as showing a substantial bearing on farmers' decisions to adopt Contract Farming practices. In literature all these factors were categorized as physical, personal, institutional as well as socio-economic.

\section{ANALYTIC FRAMEWORK AND EMPIRICAL MODEL}

\subsection{Analytic Framework for Contract Farming Adoption and its Impact on Productivity}

Farmers' decisions to participate in any production program or rather, are affected partially by the observed balance of opportunities, benefits and constraints. Therefore, in order to analyze the socioeconomic elements that impact decision of a farmer to enter into contract agreements with processors, various models could be applied to evaluate and determine the influence of those elements on decision of farmers to a contract. Discrete choice models have been applied to quantify and identify the factors affecting the likelihood of a farmer participation in a production and/or marketing institutional arrangement. The applied models involve the Probit, linear probability, Logit as well as multinomial Logit models.

However, these models cannot be used to evaluate the impact of participation in the program/contract farming although differences in output of the contract and non- contract farmers do not need inevitably be characterized by contract farming. This could be resulted from dissimilarity in intangible attributes such as management skills of this group of farmers. A comparability of average production may therefore be unfair. A solution for rectifying this biasness requires the application of a Standard Treatment Effects Model (Greene, 2003). Thus, since the FC adoption is self-selective, an easy comparison of both means of the results between farmers adopting CF and those who do not do so and an estimation of a least squares including an adoption indicator variable are unsuitable. Assumption of both methods is that the results may be comparable as adoption is considered to be a random event.

Nevertheless, unnoticed factors for instance the farmers' production and management skills would enhance both the possibility of productivity and adoption. In that perspective, the adoption as well as non-adoption results from the same individual have to be compared so as to allow evaluation of adoption effect. Since the contrary to fact is actually unobservable, there is a failure to provide appropriate comparison through the use of the above approaches, hence bringing on an inconsistency estimate regarding effect of the treatment. 
Hence, the treatment effects model which is used extensively in the literature of program evaluation (e.g., Pitt and Khandker (1998)) has been used under this study and permits us to weigh against the actual results including the counterfactual, therefore incorporate the self-selective nature of CF. Pattanayak and Mercer (2002) approximated the implications of contract farming on perceived quality of soil through the application of the treatment effects model at which point the selection bias is adjusted by the means of involving the inverse Mill's ratio just like a regressor in accordance to Heckman (1978). Caviglia-Harris (2003) had also applied the two stage sample selection model for the estimation of the agro-forestry's various effects relating to destruction of forests in the Amazon, Brazil. Kassie et al. (2008) approximated the impact of the stone bunds' adoption as a form of Soil Conservation Technologies on the crop outputs value utilizing matching-method firstly introduced (Rosenbaum \& Rubin, 1983).

Moreover, there is existence of some other studies that employ the treatment effects model for the evaluation of impact of Soil Conservation Technologies apart from agro-forestry. Warning and Key (2002) conducted a study on the evaluation of the impact of contract farming participation in Senegal, West Africa. He applied two-step equation estimation for the first stage (participation) and for the second stage (determining the impact of participation). At this point, the right hand side (RHS) of the second-stage model included the inverse Mill's ratio that was estimated from the first-stage prohibit model so as to correct the biasness of the selection of the sample resulting from participation's self-selection. Bolwig, Gibbon, and Jones (2009) investigated the impact of the organic CF participation on agro-revenue in Uganda while applying the equivalent sampling selection model, although with extremely likelihood estimation rather than the two stage method.

\subsection{Treatment Effects Model as an Empirical Model for Analysis}

A standard treatment effects model was adopted as used by Otsuki (2010);

$$
\mathrm{Y}_{\mathrm{i}}=\mathrm{X}_{\mathrm{i}}^{\prime} \beta+\delta \mathrm{I}_{\mathrm{i}}+v_{\mathrm{i}}+
$$

Where, $\mathrm{Y}_{\mathrm{i}}$, is a controlled variable presenting a result, $\mathrm{X}_{\mathrm{i}}$ a vector of exogenous variables, $\beta$ a vector of coefficient parameters for $\mathrm{X}_{\mathrm{i}}, \mathrm{I}_{\mathrm{i}}$ adoption status that is a binary treatment variable, $\delta$ a coefficient estimator for $\mathrm{I}_{\mathrm{i}}$ which is explained as a treatment effect, and $v_{i}$ an error term following normal distribution together with variance $\sigma v^{2}$ and mean zero. The adoption of individuals in reliance on a set of determinants $Z_{\mathrm{i}}$ is stated as follows:

$$
\mathrm{I}_{\mathrm{i}}^{*}=\mathrm{Z}_{\mathrm{i}}^{\prime} \gamma+\mu_{\mathrm{i}}
$$

Whereby $\mathrm{I}_{\mathrm{i}} *$ represents a latent variable while $\gamma$ stands for a vector of coefficient parameters, and $\mu_{\mathrm{i}}$ is an error term. The unobservable latent variable and its relation with $\mathrm{I}_{\mathrm{i}}$ is stated by:

$$
\mathrm{I}_{\mathrm{i}}=1 \text { if } \mathrm{I}_{\mathrm{i}}^{*}>1 \text {, otherwise } \mathrm{I}_{\mathrm{i}}=0
$$

When unobserved factors as indicated in (2) are correlated with $\nu_{\mathrm{i}}$, then the correlation coefficient between $\mu_{\mathrm{i}}$ and $v_{\mathrm{i}}$ (denoted as $\rho$ ) is non-zero, and therefore the Ordinary Least Square (OLS) estimator is inconsistent (Greene, 2008). According to Greene (2008) the anticipated result for actors supposing normal distribution for I shall become;

$$
\begin{aligned}
\mathrm{E}\left[\mathrm{Y}_{\mathrm{i}} \mid \mathrm{I}_{\mathrm{i}}=1, \mathrm{X}_{\mathrm{i}} \mathrm{Z}_{\mathrm{i}}\right]=\mathrm{X}_{\mathrm{i}}^{\prime} \beta+\delta+\mathrm{E}\left[v_{\mathrm{i}} \mid \mathrm{I}_{\mathrm{i}}=1, \mathrm{X}_{\mathrm{i}} \mathrm{Z}_{\mathrm{i}}\right] \\
=\mathrm{X}_{\mathrm{i}}^{\prime} \beta+\delta+\rho \sigma v\left[\varphi\left(\mathrm{Z}_{\mathrm{i}}^{\prime} \gamma\right) / \Phi\left(\mathrm{Z}_{\mathrm{i}}^{\prime} \gamma\right)\right],
\end{aligned}
$$

Wherever $\rho \sigma v$ matches the covariance between $v_{\mathrm{i}}$ and $\mu_{\mathrm{i}}, \varphi\left(\mathrm{Z}_{\mathrm{i}}^{\prime} \gamma\right)$ the standard normal marginal probability density at $\varphi\left(Z_{i}^{\prime} \gamma\right)$ and $\Phi\left(Z_{i}^{\prime} \gamma\right)$, the standard normal cumulative probability at $Z_{i}^{\prime} \gamma$. The $3^{\text {rd }}$ term involves the inverse Mill's ratio to have influence for bias of a possible sample selection, $\lambda=\rho \sigma v \varphi\left(Z_{i}^{\prime} \gamma\right) \div \Phi\left(Z_{i}^{\prime} \gamma\right)$, and $\beta \lambda=\rho \sigma v$ become the coefficient parameter for $\lambda_{\mathrm{i}}$. The anticipated result for non-participants shall become:

$$
\mathrm{E}\left[\mathrm{Y}_{\mathrm{i}} \mid \mathrm{I}_{\mathrm{i}}=0, \mathrm{X}_{\mathrm{i}} Z_{\mathrm{i}}\right]=\mathrm{X}_{\mathrm{i}}^{\prime} \beta+\rho \sigma v\left[-\varphi\left(Z_{\mathrm{i}}^{\prime} \gamma\right) / 1-\Phi\left(Z_{\mathrm{i}}^{\prime} \gamma\right),\right.
$$

$\left.\lambda=-\varphi\left(Z_{i}^{\prime} \gamma\right) / 1-\Phi\left(Z_{i}^{\prime} \gamma\right)\right]$ is the inverse Mill's ratio for $(5)$. Therefore, the discrepancy in the anticipated result between actors and non-actors then shall become:

$$
\mathrm{E}\left[\mathrm{Y}_{\mathrm{i}} \mid \mathrm{I}_{\mathrm{i}}=1, \mathrm{X}_{\mathrm{i}} \mathrm{Z}_{\mathrm{i}}\right]-\mathrm{E}\left[\mathrm{Y}_{\mathrm{i}} \mid \mathrm{I}_{\mathrm{i}}=0, \mathrm{X}_{\mathrm{i}} \mathrm{Z}_{\mathrm{i}}\right]=\delta+\text { selection term }
$$


The selection term with a positive sign means that Ordinary Least Square overestimates while the one with a negative sigh means Ordinary Least Square underestimates $\delta$, and also the selection term sign is influenced by that of $\rho$. Estimation of maximum likelihood has been suggested by Maddala (1983) and Greene (2008) as it generates consistent estimators. Maddala (1983) additionally suggested two-step estimation which as well generates consistent estimators. Equation 2 is estimated by a probit estimation in the initial step followed by estimates Equation 1 by involving the estimated value of selectivity correction as an added regressor. Whereas a number of investigations that assess the impact of contract farming as well as adoption of technology apply the two-stage estimation in favor of the analytic and systematic tractability; we have been using the maximum likelihood estimation. We have chosen this approach as it jointly estimates the productivity and adoption equations, and as a result it enables us to investigate the significance of the cross equation correlation $\rho$. If it would be impossible for us to attain convergence in the maximum likelihood estimation, we apply the two-stage estimation.

\section{STUDY SITE, SAMPLING PROCEDURE AND DATA COLLECTION TECHNIQUE}

3.1. Study Site

The empirical data for this study depends on cross-sectional survey data of household attributes, seed cotton production and marketing collected in Bunda District in September to December, 2014 for a PhD thesis. As reported by the housing and population census 2002, Bunda District had a population of 266,000. The estimated population in each ward was 13,300 while in each village, the estimated population was 2,900 and main occupations included agriculture, livestock and fishing.

\subsection{Sampling Procedure}

According to Aday (1996) in order to estimate a proportion of 50\% for two groups (contract and non-contract farmers) with a desired precision of $0.05 \%$, the recommended sample size is 384 respondents. Therefore, sample size of 400 households for survey was sought for this study where 200 contract and 200 non contract farmer households were planned to be interviewed. The researcher used multistage sampling techniques and started by selecting six (6) wards out of twenty-four (24) that grow cotton purposively. The six wards were selected because they were the ones involved in pilot cotton contract farming. In each of the six wards selected, one village was purposively selected where the final sample was drawn for the same reasons as for the wards.

Since the average household size in Bunda District was 6.8, where each village has an average of 426 households. According to TCB officials during the pilot study, each village had a total of 48 to 80 households that grow cotton out of the cumulative total of 426 households in every single village. Therefore, cotton farmers in all the six villages ranged from $288(48 \times 6)$ to 480 (80x6) households. Since the plan was to collect data from 400 cotton farmers, the researcher decided to sample all households involved in cotton farming in all the six villages in order to get the required number of respondents. For that case $100 \%$ of the cotton farmers in villages sampled were included in the survey and this resulted in a total number of 414 households responded to personally administered questionnaire. 220 out of 414 respondents were contract farmer households while 194 out 414 respondents were non-contract farmers.

\subsection{Data Collection Technique}

Primary quantitative data were collected by the use of personally administered questionnaires where the total number of 414 questionnaires was administered by four trained research assistants in the specific wards. The enumerators started by asking consent of respondents before they administered or interviewed them.

As pointed out in Section 3.2 above, 220 contract farmer households responded and provided answers to the personally administered questionnaire while 194 non-contract farmer households responded to the personally administered questionnaire although the plan was to interview 200 respondents for each group. Where household 
heads were not available, replacement was made by the researcher. Questionnaires are advantageous over several other forms of surveys because they are inexpensive, there is no requirement for a lot of effort from the researchers like telephone or verbal surveys, and frequently provide standardised responses that simplify data compilation.

To achieve the purpose of getting reliable data, enumerators had to read-out questions precisely following the same procedure in accordance to how they prepared on the questionnaire. The addressed questions were highly specific and very frequently offered the respondents answers in a fixed range (closed end questions) as well as very seldom some few questions offered the same respondents with flexible range of answers (open ended questions). However, interviewees were given flexibility in answering questions as well as in seeking clarification when the question asked was not well understood by a respondent. In order to obtain valid information about the sampled household, one respondent from each household was interviewed. Heads of households were the most preferred to respond to our questions due to their positions of having more and appropriate information about the household than anybody else, but in circumstances where the head was not available or was not able to be interviewed, any available member who participated in $\mathrm{CF}$ and was ready and able to offer the required data was interviewed. After the examination of data and cleaning, the researcher came out with 400 clean questionnaires for analysis where 211 were for contract farmer households and 189 were for non-contract farmer households. The details of the sample selected for questionnaire administration and the number of respondents in each ward is shown in Table 1 below;

Table-1. Personally administered questionnaires

\begin{tabular}{c|c|c|c|c|c}
\hline S/No & Ward & Village & $\begin{array}{c}\text { Contract } \\
\text { households }\end{array}$ & $\begin{array}{c}\text { Non-contract } \\
\text { households }\end{array}$ & $\begin{array}{c}\text { Total number } \\
\text { of respondents }\end{array}$ \\
\hline 1 & Wariku & Kamkenga & 43 & 45 & 88 \\
\hline 2 & Guta & Guta & 47 & 40 & 87 \\
\hline 3 & Nyamang'uta & Kiroreli & 42 & 41 & 83 \\
\hline 4 & Nyamuswa & Nyamuswa & 15 & 25 & 40 \\
\hline 5 & Hunyari & Mariwanda & 38 & 21 & 59 \\
\hline 6 & Namuhura & Karukekere & 35 & 22 & 47 \\
\hline \multicolumn{7}{l}{ Source: Field data, 2014.} & 220 & 194 & \\
\hline
\end{tabular}

\subsection{Data Analysis using Treatment Effects Model Specifications}

Since the maximum likelihood estimation was used, the production function used was in the form of;

lnOutput $=\beta \mathrm{o}+\beta_{1} \ln \mathrm{TLD}+\beta_{2} \ln \mathrm{TL}+\beta_{3} \ln \mathrm{TS}+\mathrm{TPD} \beta_{4} \ln \mathrm{TP}+\mathrm{TCD} \beta_{5} \ln \mathrm{TCA}+\mathrm{EI}$ where:

$\ln \quad=$ denotes logarithms to base $\mathrm{e}$

Output $=$ the maximum attainable output for a given level of all inputs, measured in $\mathrm{kg}$ per acre.

TLD = Land used for cotton cultivation measured in acres.

TL = Total labour (Family and hired) utilised, measured in man-days.

TS $=$ Amount of cotton seed used in planting cotton measured in kgs

$\mathrm{TP}=$ Amount of pesticides used to cotton measured in bottles (acre packs)

TCA = The value of total capital equipment (Agricultural assets) measured in Tsh.

TPD = Dummy variable for pesticides (1 for farmers used, o for farmers not used)

TCD = Dummy variable for capital ( 1 for famers with capital, o for farmers without)

TLCOC $=$ Total land cultivated other crops

Bi's = are unknown parameters to be estimated.

While the adoption equation was represented by the following equation;

Ftype $=\{$ Hhage, Hheduc, Hhsize, Hhsex, Exper, Mcycle, Loan, Cow, Tv, Radio, bicycle, Wages, Offfarm $\}$ Where;

Hhage $=$ Age of the farmer in years 
Hheduc $=$ Level of education of the farmer in years

Hhsize $=$ Family/household size taken as total number of family members

Ftype $=$ Farming type ( 1 for contractual arrangement, $\mathrm{o}$ for no contract arrangement $)$

Exper $=$ Farmers' experience in cotton cultivation expressed in years

$\mathrm{TV}=1$ for Farmers possessing a TV, o otherwise

Mcycle $=1$ for farmers possessing motorcycle, 0 otherwise

Radio $=1$ for Farmers possessing a radio, o otherwise

Cow $=1$ for Farmers possessing cows, o otherwise

Loan $=1$ for farmers who access loan, 0 otherwise

Wages $=1$ for farmers paid wages, 0 otherwise

Offfarm $=1$ for farmers having off farm activities, $\mathrm{O}$ otherwise

Bicycle $=1$ for farmers having bicycles, 0 otherwise

\section{RESULTS AND DISCUSSION}

\subsection{Summary Statistics of Households}

Before making a detailed discussion on adoption of CF and its impact on productivity, the researcher preferred first to present the summary statistics of variables applied in the entire analysis of data. Table 2 shows the summary statistics for 211 contract farm workers along with 189 non-contract farm workers producing amount of 400 farmers. Summary statistics provide informed results among two groups of farmers before comparing their productivity.

By looking at the summary statistics for contract farmers, the mean output for an average of 4.23 acres was 1021.41 Kilograms (kgs) with a minimum output of $10 \mathrm{kgs}$ and maximum output of $8460 \mathrm{kgs}$ of seed cotton which is equivalent to $241.47 \mathrm{kgs}$ of seed cotton per acre. The mean of total land cultivated cotton was found to be 4.23 acres with a minimum of 1 acre and a maximum of 25 acres for contract farmers. For the case of capital, the average capital for contract farmers was found to be Tanzania Shillings (TShs.) 730,399.3/= with a minimum of TShs. 1000.00 and a maximum of TShs. $18,824,840 /=$ while the mean labour was found to be 103.42 man-days with a minimum of 4 man-days and a maximum of 484 man days for contract farmers. Mean seed used was $51.27 \mathrm{kgs}$ with a minimum of $6 \mathrm{kgs}$ and maximum of $250 \mathrm{kgs}$ of cotton seed while mean pesticides used was 23.39 bottles (acre packs) with a minimum of 1 acre pack and a maximum of 175 bottles (acre packs). In addition, the mean contract farmers' age was found to be 44.23 years with age limitation starting from 20 years up to 90 years while the mean experience of farmers happened to be 12.94 years, at a lower limit age of 1 year and a higher limit age of 58 years in cottongrowing. The mean family size was found to be 6.6 people with a minimum of one family member and a maximum of 10 family members while the mean land cultivated for other crops was found to be 5.78 acres with a minimum of 0.00 acre and a maximum of 44 acres cultivated by contract farmers for other crops.

The situation was almost the same for non-contract farmers. By looking on the summary statistics, the mean output for an average of 3.28 acres was $675.43 \mathrm{kgs}$ with a minimum output of $20 \mathrm{kgs}$ and maximum output of 6,300 $\mathrm{kgs}$ of seed cotton which is equivalent to $205.92 \mathrm{kgs}$ of seed cotton per acre. The mean of total land cultivated cotton was found to be 3.28 acres with a minimum of 1 acre and a maximum of 24 acres for noncontract farmers. For the case of capital, the average capital for non-contract farmers was found to be TShs. 946,311/= with a minimum of TShs. 0.00 and a maximum of TShs. $20,040,000 /=$ while the mean labour was found to be 81.68 mandays with a minimum of 6 man days and a maximum of 540 man days for non-contract farmers. Mean seed used was $34.76 \mathrm{kgs}$ with a minimum of $8 \mathrm{kgs}$ and maximum of $240 \mathrm{kgs}$ of cotton seed while mean pesticides used was 17.50 bottles (acre packs) with a minimum of one (1) acre pack and a maximum of 140 acre packs. In addition, the average non-contract farmers' age was found to be 44.29 years with a lower limit age of 22 years and higher limit age of 89 years while the mean experience of farmers was 11.24 years, with a lower limit of 1 year and a higher limit of 60 
years in cotton-growing. The mean family size was found to be 6.06 people with a minimum of one family member and a maximum of 12 family members while the mean land cultivated for other crops was found to be 5.41 acres with a minimum of 0.00 acre and a maximum of 33 acres cultivated by non-contract farmers for other crops.

Table-2. Summary statistics for the smallholder cotton farmers surveyed.

\begin{tabular}{|c|c|c|c|c|c|c|c|c|c|c|}
\hline \multicolumn{6}{|c|}{ Contract farmers } & \multicolumn{5}{|c|}{ Non-contract farmers } \\
\hline Variable & Obs & Mean & Std. Dev. & Min & Max & Obs & Mean & Std. Dev. & Min & Max \\
\hline $\begin{array}{l}\text { Output in } \\
\text { kgs }\end{array}$ & 211 & 1021.408 & 1208.349 & 10 & 8460 & 189 & 675.4339 & 892.3113 & 20 & 6300 \\
\hline TLD in acres & 211 & 4.227488 & 3.317042 & 1 & 25 & 189 & 3.277778 & 3.828898 & 1 & 24 \\
\hline $\mathrm{TS}$ in kgs & 211 & 51.27014 & 45.61524 & 6 & 250 & 189 & 34.75661 & 38.80384 & 8 & 240 \\
\hline $\mathrm{TP}$ in bottles & 211 & 23.38863 & 22.39219 & 1 & 175 & 189 & 17.49735 & 22.56778 & 1 & 140 \\
\hline $\begin{array}{l}\text { TCA in } \\
\text { TShs. }\end{array}$ & 211 & 7303.993 & 18824.84 & 1 & 190000 & 189 & 9463.111 & 26407.89 & 1 & 200040 \\
\hline $\begin{array}{c}\text { TL in Man } \\
\text { days }\end{array}$ & 211 & 103.4218 & 88.98843 & 4 & 484 & 189 & 81.67725 & 75.98325 & 6 & 540 \\
\hline $\begin{array}{c}\text { EXPER in } \\
\text { years }\end{array}$ & 211 & 12.94313 & 11.37276 & 1 & 58 & 189 & 11.2381 & 12.44056 & 1 & 60 \\
\hline $\begin{array}{l}\text { HHSIZE in } \\
\text { number }\end{array}$ & 211 & 6.57346 & 2.557539 & 1 & 10 & 189 & 6.063492 & 2.588064 & 1 & 12 \\
\hline $\begin{array}{c}\text { HHAGE in } \\
\text { years }\end{array}$ & 211 & 44.22749 & 14.21587 & 20 & 90 & 189 & 44.29101 & 14.11258 & 22 & 89 \\
\hline $\begin{array}{l}\text { TLCOC in } \\
\text { acres }\end{array}$ & 211 & 5.781991 & 5.853762 & $\mathrm{O}$ & 44 & 189 & 5.412698 & 5.14565 & $\mathrm{O}$ & 33 \\
\hline
\end{tabular}

\subsection{Determinants of Contract Farming (CF) Adoption on Seed Cotton Production}

Providing summary statistics on contract farmers and non-contract farmers was not sufficient to justify the reasons for joining or not joining contract farming and its impact on productivity. Therefore, the researcher decided to find out determinants of farmers to joined contract farming. As explained in analytic framework, treatment effects model was used in this case.

Our econometric modeling to examine the impact of the adoption of contract farming and its impact on productivity, that we express it as the equation of productivity of which is indicated by establishing productivity index equally to $\mathrm{Y}_{\mathrm{i}}$, exogenous factors to impact $\mathrm{Y}_{\mathrm{i}}$ like $\mathrm{X}_{\mathrm{i}}$, along with the adoption dummy of contract farming equally to $\mathrm{I}_{\mathrm{i}}$ in Equation 1 indicated at section 2.2 above. The adoption equation is given by establishing the exogenous determinants of the adoption of contract farming as $Z_{\mathrm{i}}$ in Equation 2 of the same section. A total of 400 observations were used, where 211 are contract farmers and 189 non-contract farmers.

Table 3 provides the outcomes of both the adoption and productivity equations. The table indicates the estimate of coefficient as well as the standard error of every variable together with $\lambda$ (the inverse Mill's ratio). Furthermore, the table indicates the coefficient parameter $\rho$ estimate for the adoption and productivity equations, as well as the statistics of chi-squared concerning the Wald test for predictability of a model. The Wald test p-values concerning the propose significance of the coefficient parameters at the significance of 5 percent of the model, implying good model predictability. Thus, the likelihood ratio chi-square statistic is equivalent to 226.85 with $7^{\circ}$ of freedom denies the null hypothesis of which the parameter estimates for the model are equivalent to 0 at 5 per cent significance level. We can conclude that the model explanatory capacity is acceptable which means the model is allowed to justify the probability of contract farming adoption by the smallholder cotton farmers.

The outcomes of the adoption equation indicate that gender of household head, household head age, experience in cotton cultivation, obtaining loan from other sources, being paid wages, owning cattle, owning TV and owning a bicycle have influence in adopting contract farming, confirming the results in the previous studies.

Thus, Table 3 indicates the male-headed households (Hhsex) were at higher degree to adopt contract farming compared to female headed household $(\mathrm{r}=0.81615, \mathrm{p}<0.05)$. This can be explained by the masculinity nature of 
families in Bunda District where male tend to govern household decisions compared to women. This leads to male headed household opt to adopt contract farming quicker than female headed household. This is supported by the study conducted by Marenya and Barrett (2007) who discovered that Male-headed households were statistically significantly at higher degree to adopt practices of better natural resources management among small-holder farmers in the Western Kenya as compared to female-headed households. In a study done by Bellemare (2012) and Wainaina, Okello, and Nzuma (2012) documented that female could hardly be likely to adopt contract farming as compared to males in Kenya, Madagascar and China respectively. When talking about developing countries, one possible explanation is that, institutional forces can offer females with unfavorable contract conditions or opportunities.

Also, Age (Hhage) and farming experience (Exper) tend to behave similar in adopting contract farming but in this case age was not important factor in deciding farmers to adopt contract farming practices but experience in cotton cultivation seemed to be one of the factors influencing adoption of CF. Under this case, more experienced farmers were most likely to engage themselves in CF in comparison with less experienced farmers. Thus, there exists a positive relation between experiences (Exper) with contract farming adoption practice. The regression outcomes imply that the more time a household is involved in cotton cultivation, the more likely it is to adopt contract farming $(r=0.0129188, \mathrm{p}<0.05)$. This is supported by a study done by Guo (2005) who pointed out that engagement in agro-activities will raise the acceptance possibility of $\mathrm{CF}$. The implication is that agricultural experience as well has things to do with $\mathrm{CF}$ acceptance. In addition, they emphasize that the experienced individuals in agriculture have a favorable views toward contract production as well as they wishes to be engaged themselves in CF whenever offering them the opportunities. Guo and Jiang (2007) additional emphasize that CF acceptance is influenced by type of enterprise, public policy, attributes of marketplace and the characteristics of farm's production. The requirements of quality for supplied raw materials, public support policies and price volatility motivate firms to make use of contracts.

In addition, farmers owning bicycles $(r=0.1888, \mathrm{p}<0.05)$ and TVs $(\mathrm{r}=0.244559, \mathrm{p}<0.10)$ were found to adopt contract farming compared to the ones not owning them. The reason behind is that bicycles and TVs were regarded as home equipment and used by contract farmers as collaterals when they fail to pay their input loans in their respective FBGs. In the meantime, the ones had no bicycles and TVs had nothing to offer as collateral when required to do so. In addition, bicycles were used as a sign of wealth and means of transport during the planting, weeding and harvest time which made farmers to arrive earlier to farms in order to start working. TVs were used as source of information (extension services) relating to cotton production (sowing, thinning, weeding, spraying, harvesting, storage) and marketing (selling). This is supported by the study done by Dhillon and Singh (2006) on the contract farming in Punjab who discovered that majority of the farmers who preferred CF were induced to make the choice by Government advertisement on newspapers, radio or television to draw attention on $\mathrm{CF}$ as a solution from the current crisis of agrarian.

Farmers who access loan/credit from various sources/financial institution adopt contract farming easily compared to the ones who do not have loan access $(r=0.24476, p<0.01)$. This could be defined for the reason that farmers with access to loans have gained experience in dealing with credit market; hence, they are not afraid of receiving inputs on credit. Their experience in sourcing loan from various sources has enabled them to learn the proper use of credit where the same knowledge can be applied to manage input credit. This concurs with finding made by Saigenji (2010) who found that $4 \%$ of non-tea farmers cite face difficulties in accessing to credit because they did not participate in tea production. Credit accessibility for tea production was essential due to great initial expenses because of a long period of vegetation for allowing harvest, and as a cash crop. It often requires intensive input regime (Key \& Runsten, 1999) relative to that of traditional crops.

Age (Hhage) of the farmer, owning cows by the farmer and being paid wages had negative coefficients showing that these variables had negative correlation with contract farming adoption. With age, old farmers tend not to 
adopt contract farming compared to younger farmers $(\mathrm{r}=-0.0100423, \mathrm{p}<0.10)$. This could be explained due to the fact that aged farmers become more worried to adopt new technology compared to younger farmers. This can be supported by the investigation on the adoption of soil conservation in the Philippines' uplands indicated that age had both positive and negative influence on decisions of adopting contour hedgerows in Claveria and Cebu respectively (Lapar \& Pandey, 1999). Baidu-Forson (1999) has reached the conclusion that age adversely affected the land adoption as well as intensifying technology in the Sahel. His analysis pointed out that effect of age would have been influenced by the farmer's changing life cycle as time goes by, and the impact on adoption of contract farming practices. As farmers ageing, they turn-out to be more skilled, by the means of action learning. Besides, this trend lessened when farmers get to middle age as well as their physical stamina start to weaken. Additionally, with age farmers be even more risk-averse as well as increasingly reluctant to adopt latest farming technologies (Mazvimavi \& Twomlow, 2009).

As expected, owning cows significantly and negatively influenced adoption of contract farming compared to farmers not owning cows $(\mathrm{r}=-0.23833, \mathrm{p}<0.10)$. This is because farmers owning cattle would not need cultivation services from ginners using tractors for them to cultivate large areas. In the meantime, the ones without cows would need such a service in order to cultivate their respective plots. Also, having cows would mean that farmers could use farmyard manure to fertilize their plots in order to increase productivity. In this case, farmers who had no cattle would prefer to adopt contract farming. This result does not support the findings made by Marenya and Barrett (2007) who found that the livestock value was positively as well as significantly related with adoption of the Agroforestry, manure and inorganic fertiliser practices.

Farmers who have paid wages tend not to adopt contract farming compared to farmers who have no paid wages $(\mathrm{r}=-0.424587, \mathrm{p}<0.10)$. This is because the ones paid wages have the ability to buy inputs (seeds and pesticides) during the cotton production compared to the ones not being paid wages. Since they have the ability to buy input on cash basis, farmers who have paid wages find no reason to engage in contract farming by being provided inputs on credit worth less than TShs. 10,000/= in exchange of exclusive purchasing right for all the cotton produced by the farmer. This is contrary to the findings that show technology adoption is influenced by the extent of nonagricultural revenue-generation activities. Non-agricultural revenue has been effectively identified as essential component of what does it mean to be a subsistence farmers in South Africa (Aliber \& Hart, 2010 cited in Van Den Berg (2013)).

\subsection{Impact of Contract Farming (CF) Adoption on Seed Cotton Production}

Results from Table 3 above shows that there is no significant impact and contribution brought out by $\mathrm{CF}$ on productivity of smallholder cotton producers in Bunda District since the coefficient of CF adoption dummy (Ftype) variable in the treatment effects model is a negative (-0.3759668) with a $\mathrm{P}$ value of 0.211 which is insignificant even at $10 \%(\mathrm{P}>10 \%)$. This result does not confirm the theory that concerned with cotton $\mathrm{CF}$ was more cost effective in comparison with independent productions. This outcome supports the research done by BoT (2016) which found no significant connection existing between contract and non-contract cotton farmers, largely due to delay of inputs and low quality seeds. But contradict (Tiongco, Catelo, \& Lapar, 2007) who found that participating in contract farming benefited farmers. Factors seem to affect productivity from the results shown on Table 3 are cotton seeds, pesticides, capital and labour. Pesticide is the factor with highest effect on productivity compared to other factors.

Findings from in-depth interviews conducted to contract farmers, non-contract farmers, Farmers Business Groups leaders and ginners show that contract arrangement did not work well since the contract used in contract farming was incomplete and it had short falls. The incompleteness of the contract resulted for buyers and farmers not to fulfilment their contractual obligations. On the one hand, buyers delayed to supply cotton seed to farmers timely which resulted in delaying to sow the seeds as per the cultivation calendar. Late sowing led to low seed 
cotton yield per acre. On the other hand, some farmers sold part of cotton seed given on credit by ginners to noncontract farmers.

Table-3. Treatment-effects model -- two-step estimates for factors influencing adoption of CF and its impact on seed cotton production.

\begin{tabular}{|c|c|c|c|c|c|c|}
\hline \multicolumn{7}{|c|}{ Production equation } \\
\hline & Coef. & Std. Err. & $\mathbf{Z}$ & $\mathbf{P}>\mathbf{z}$ & [95\% Conf. & Interval] \\
\hline \multicolumn{7}{|l|}{ Lnoutput } \\
\hline LnTLD & 0.0492791 & 0.1841081 & 0.27 & 0.789 & -0.3115661 & 0.4101243 \\
\hline Lnts & 0.2671801 & 0.1551587 & 1.72 & 0.085 & -0.0369254 & 0.5712856 \\
\hline LnTP & 0.4814406 & 0.0952895 & 5.05 & 0.000 & 0.2946767 & 0.6682045 \\
\hline Tpd & 1.403048 & 0.3232871 & 4.34 & 0.000 & 0.7694173 & 2.036679 \\
\hline Lntca & 0.0500095 & 0.019298 & 2.59 & 0.010 & 0.0121861 & 0.087833 \\
\hline LnTL & O.1497934 & 0.0610359 & 2.45 & 0.014 & 0.0301653 & 0.2694216 \\
\hline Ftype & -0.3759668 & 0.300738 & -1.25 & 0.211 & -0.9654024 & 0.2134687 \\
\hline _cons & 3.070563 & 0.4768364 & 6.44 & 0.000 & 2.135981 & 4.005145 \\
\hline \multicolumn{7}{|c|}{ Adoption equation } \\
\hline \multicolumn{7}{|c|}{ Ftype } \\
\hline Exper & 0.0129188 & 0.0065631 & 1.97 & 0.049 & 0.0000553 & 0.0257823 \\
\hline Hhsize & 0.0448549 & 0.0278629 & 1.61 & 0.107 & -0.0097553 & 0.0994651 \\
\hline Hhsex & 0.8161524 & 0.2505103 & 3.26 & 0.001 & 0.3251613 & 1.307143 \\
\hline Hhage & -0.0100423 & 0.0059101 & -1.70 & 0.089 & -0.0216259 & 0.0015412 \\
\hline Loan & 0.7321797 & 0.2447624 & 2.99 & 0.003 & 0.2524542 & 1.211905 \\
\hline Offfarm & -0.2087713 & 0.1365779 & -1.53 & 0.126 & -0.476459 & 0.0589164 \\
\hline Wages & -0.4245871 & 0.2262595 & -1.88 & 0.061 & -0.8680476 & 0.0188735 \\
\hline Hheduc & -0.2724951 & 0.3338644 & -0.82 & 0.414 & -0.9268572 & 0.3818671 \\
\hline Mcycle & 0.0862424 & 0.1335783 & 0.65 & 0.519 & -0.1755662 & 0.348051 \\
\hline Cow & -0.2383286 & 0.1403672 & -1.70 & 0.090 & -0.5134433 & 0.036786 \\
\hline $\mathrm{TV}$ & 0.4471829 & 0.244559 & 1.83 & 0.067 & -0.0321439 & 0.9265097 \\
\hline Radio & -0.0683238 & 0.2008397 & -0.34 & 0.734 & -0.4619624 & 0.3253149 \\
\hline Bicycle & 0.5279893 & O.1888063 & 2.80 & 0.005 & 0.1579357 & 0.8980428 \\
\hline _cons & -0.6933262 & 0.4730793 & -1.47 & 0.143 & -1.620545 & 0.2338922 \\
\hline Hazard Lambda & 0.3163403 & 0.1911025 & 1.66 & 0.098 & -0.0582137 & 0.6908943 \\
\hline Rho & 0.32380 & & & & & \\
\hline Sigma & 0.97695335 & & & & & \\
\hline $\operatorname{Lambda}(\lambda)$ & 0.3163403 & & & 0.191 & & \\
\hline
\end{tabular}

Source: Field data, 2014.

This led to using less than 10 kilograms of cotton seed per acre as recommended by Tanzania Cotton Board (TCB) which resulted also in low yield of seed cotton produced per acre. Pesticides were distributed again late to contract and non-contract farmers and in less quantity. Those in contract farming were given only three acre packs (bottles) instead of six (6) acre packs per acre as recommended by TCB on loan basis while non-contract farmers purchased on cash basis any amount they wish at any time. Since plots of contract and non-contract farmers were found in neighbouring areas, applying fewer pesticides in one plot say of a contract farmer while the neighbouring plot of a non-contract farmer was not sprayed, was meaningless. With the water formulation pesticides, after few minutes, pests would shift to the sprayed plot and keep on destroying the cotton boll. Water formulated pesticides did not kill pests as for the case of oil formulated pesticides, they just put pests in dormant state. This situation caused low yield of seed cotton to contract farmers as for the non-contract farmers' case. In the meantime, sprayers were sold to Farmers Business Groups (FBGs) on cash basis at TShs. 50,000/= instead of being given on credit as agreed in the contract. In most cases, lead farmers or one among FBG leaders were the ones who bought the spray pumps. The tendency of having one sprayer for a Farmer Business Group having up to 90 members made it difficult to spray cotton and control pests effectively. This led to low yield in seed cotton production among group members as for the case of non-contract farmers who do not possess sprayers. Fertilizer which is also among the factors of 
production was not distributed by buyers to all groups of farmers but few farmers both contract and non-contract farmers apply farmyard manure. The cotton production for farmers who use farmyard manure is very high compared to farmers who do not use such manure whether they are in contract farming or not. Therefore, the tendency of not using fertilisers in seed cotton production is among of the causes of low seed cotton production in Bunda District to contract and non-contract farmers. In addition, some ginners provided cultivation services using tractors at a rate of TShs. 40,000/= per acre where contract farmers had to pay TShs. 30,000/= upfront while TShs. $10,000 /=$ was to be paid during the marketing season. But cultivation service was also offered to noncontract farmers by paying all the TShs. 40,000/= upfront. Again, the difference was only TShs. 10,000/= between the two groups to access the service. But sometimes, non-contract farmers negotiated with ginners to be given cultivation services on loan basis as they did to contract farmers. However, majority of contract farmers didn't manage to pay the required amount of TShs. 30,000/= in order to get the service that could result in increase of productivity. Although contract farming proved to have no impact to farmers, data from survey shows that 148 out of 211 contract farmers included in the sample equivalents to 70.5 percent were willing to continue participating in contract farming as shown in Table 4.

Table-4. Willingness of contract farmers continue with Contract farming.

\begin{tabular}{c|c|c|c|c}
\hline S/No & Response & Frequency & Percent & Cumulative Percent \\
\hline 1 & Yes & 148 & 70.5 & 70.5 \\
\hline 2 & No & 63 & 29.5 & 100.0 \\
\hline \multicolumn{4}{l}{ Source: Field data, 2014. } \\
\hline
\end{tabular}

\section{CONCLUSION AND POLICY IMPLICATION}

\subsection{Conclusion}

The objective of this study was to analyse the reasons for farmers to join contract farming. That is why farmers adopt contract farming and its impact on productivity among smallholder cotton producers in Tanzania. This was achieved by determining characteristics of contract farmers and the impact of contract farming on productivity among smallholder cotton farmers in Bunda District. Treatment effects model was employed using cross sectional data covering 400 smallholder cotton farmers surveyed in Bunda District to find out the contract farming adoption determinants and its impact on productivity. The results obtained from the treatment effects model show that gender of household head, household head age, experience in cotton cultivation, household size, obtaining loan from other sources, being paid wages, owning cows, owning TV and owning a bicycle had influence in adopting contract farming. In addition, some wealthier farmers who were also lead farmers were convinced by TCB and Tanzania Gatsby Trust foundation (TGT) to join contract farming in order to attract other farmers to join contract farming.

\subsection{Policy Implication}

Basing on the key results of this study, firstly, it is proposed that the Government of the United Republic of Tanzania (URT) via the Ministry of Agriculture, Food Security and Cooperatives, Tanzania Cotton Board and Tanzania Gatsby Trust who is the financier of contract farming should work strategically to convince smallholder cotton farmers to join contract farming. A voluntary form of joining contract farming should be used where education and sensitisation of farmers by telling them the advantages of CF should be formulated. Special program should be prepared on how farmers would be reached and educated on the benefits of CF at Regional, District and macro-level national wide. Secondly, with regard to impact of contract CF to productivity of smallholder cotton farmers in the study area, since ginners have not fulfilled their contractual obligations as required, it is proposed that they should fulfill their obligations by supplying cotton seed and pesticides timely as agreed in the contract so that they may be used by farmers accordingly in order to increase productivity. Also, ginners have to provide 
cultivation services to contract farmers on loan basis in order to increase plots planted cotton and distribute spray pumps to FBGs on loan basis that will enable farmers to manage their farms properly and increase productivity.

Thirdly, since some of the smallholder cotton farmers were unwilling to join CF, the government of the United Republic of Tanzania through the Ministry of Agriculture, Food Security and Cooperatives, Tanzania Cotton Board as well as Tanzania Gatsby Trust should launch major campaign to smallholder cotton farmers in order to educate them on the advantages of contract farming and the way it works. Otherwise, if proper education is not given to smallholder cotton farmers, contract farming implementation will be a nightmare.

Funding: This study received no specific financial support.

Competing Interests: The author declares that there are no conflicts of interests regarding the publication of this paper.

Acknowledgement: In submitting this paper, Author sincerely wish to present his gratitude and appreciation to my sponsor, The Danish Fellowship Centre and in particular the Potentials and Limitations of Contract Farming (POLICOFA) project for the support by providing him a scholarship through which he was able to undertake and to accomplish Ph.D. studies at the Mzumbe University. Long live prof. Joseph Andrew Kuzilwa who was the Project leader and the ex-vice chancellor of the Mzumbe University; long live the POLICOFA team 2011-2015 for enhancing his academic excellence.

\section{REFERENCES}

Abdullah, A. A., \& Sulaiman, N. N. (2013). Factors that influence the interest of youths in agricultural entrepreneurship. International Journal of Business and Social Science, 4(3), 288-302.

Aday, L. (1996). Designing and conducting health surveys. San Francisco: Jossey-Bass.

ASDS. (2001). Agricultural sector development strategy report (ASDS): Government Programme Document, 2001 (pp. 4). Ministry of Agriculture and Livestock Development, United Republic of Tanzania.

Azman, A., D'Silva, J. L., Samah, B. A., Man, N., \& Shaffril, H. A. M. (2013). Relationship between attitude, knowledge, and support towards the acceptance of sustainable agriculture among contract farmers in Malaysia. Asian Social Science, 9(2), 99-105. Available at: https://doi.org/10.5539/ass.v9n2p99.

Baidu-Forson, J. (1999). Factors influencing adoption of land-enhancing technology in the Sahel: Lessons from a case study in Niger. Agricultural Economics, 20(3), 231-239. Available at: https://doi.org/10.1111/j.1574-0862.1999.tbo0569.x.

Bellemare, M. F. (2012). As you sow, so shall you reap: The welfare impacts of contract farming. World Development, 40(7), 14181434. Available at: https://doi.org/10.1016/j.worlddev.2011.12.008.

Bolwig, S., Gibbon, P., \& Jones, S. (2009). The economics of smallholder organic contract farming in tropical Africa. World Development, 37(6), 1094-1 104. Available at: https://doi.org/10.1016/j.worlddev.2008.09.012.

BoT. (2016). Contract farming schemes in Tanzania: Benefits and challenges. Bank of Tanzania Working Paper No. 8.

Caviglia-Harris, J. L. (2003). Sustainable agricultural practices in Rondonia, Brazil: Do local farmer organizations affect adoption rates? Economic Development and Cultural Change, 52(1), 23-49. Available at: https://doi.org/10.1086/380137.

CSDSII. (2010). The second cotton sector development strategy (CSDS II): 2009- 2015: A stakeholder roadmap for increased production, productivity and profitability of cotton (pp. 10). Government Programme Document. Ministry of Agriculture and Livestock development, United Republic of Tanzania.

Dhillon, S. S., \& Singh, N. (2006). Contract farming in Punjab: An analysis of problems, challenges and opportunities. Pakistan Economic and Social Review, 44(1), 19-38.

Diiro, G. M., \& Sam, A. G. (2015). Agricultural technology adoption and nonfarm earnings In Uganda: A semi parametric analysis. The Journal of Developing Areas, 49(2), 145-162. Available at: https://doi.org/10.1353/jda.2015.0013.

Dolan, C., \& Humphrey, J. (2000). Governance and trade in fresh vegetables: The impact of UK supermarkets on the African horticulture industry. Journal of Development Studies, 37(2), 147-176. Available at: https://doi.org/10.1080/713600072.

Feder, G., Just, R. E., \& Zilberman, D. (1985). Adoption of agricultural innovations in developing countries: A survey. Economic Development and Cultural Change, 33(2), 255-298. Available at: https://doi.org/10.1086/451461.

Greene, W. H. (2003). Econometric analysis. New Jersey: Prentice Hall. 
Greene, W. H. (2008). Econometric analysis (6th ed.). New Jersey: Prentice-Hall.

Guo, H. (2005). An analysis of the influencing factors of Chinese farmers' participation in contract farming. Chinese Rural Economy, 3, 24-32.

Guo, H., \& Jiang, W. (2007). Practice and implications of the contract farming model of association+ firm+ cooperative+ farms. Chinese Rural Economy, 4, 48-52.

Hall, R., Scoones, I., \& Tsikata, D. (2017). Plantations, outgrowers and commercial farming in Africa: Agricultural commercialisation and implications for Agrarian change. The Journal of Peasant Studies, 44(3), 515-537. Available at: https://doi.org/10.1080/03066150.2016.1263187.

Haneishi, Y., Maruyama, A., Takagaki, M., \& Kikuchi, M. (2014). Farmers' risk attitudes to influence the productivity and planting decision: A case of rice and maize cultivation in rural Uganda. African Journal of Agricultural and Resource Economics, 9(4), 309-322.

Harris, S. (1992). Kenya horticulture sub-sector survey. Nairobi, Kenya: Export Development Support Project.

Heckman, J. J. (1978). Dummy endogenous variables in a simultaneous equation system. Econometrica, 46(4), 931-959. Available at: https://doi.org/10.2307/1909757.

Kassie, M., Pender, J., Yesuf, M., Kohlin, G., Bluffstone, R., \& Mulugeta, E. (2008). Estimating returns to soil conservation adoption in the Northern Ethiopian highlands. Agricultural Economics, 38(2), 213-232. Available at: https://doi.org/10.1111/j.1574-0862.2008.00295.x.

Key, N., \& Runsten, D. (1999). Contract farming, smallholders, and rural development in Latin America: The organization of agroprocessing firms and the scale of outgrower production. World Development, 27(2), 381-401. Available at: https://doi.org/10.1016/s0305-750x(98)00144-2.

Lapar, M. L. A., \& Pandey, S. (1999). Adoption of soil conservation: The case of the Philippine uplands. Agricultural Economics, 21(3), 241-256. Available at: https://doi.org/10.1016/s0169-5150(99)00028-6.

Maddala, G. S. (1983). Limited-dependent and qualitative variables in econometrics. New York: Cambridge University Press.

Mango, N., Makate, C., Tamene, L., Mponela, P., \& Ndengu, G. (2018). Adoption of small-scale irrigation farming as a climatesmart agriculture practice and its influence on household income in the Chinyanja Triangle, Southern Africa. Land, 7(2), 1-19. Available at: https://doi.org/10.3390/land7020049.

Marenya, P. P., \& Barrett, C. B. (2007). Household-level determinants of adoption of improved natural resources management practices among smallholder farmers in western Kenya. Food Policy, 32(4), 515-536. Available at: https://doi.org/10.1016/j.foodpol.2006.10.002.

Mazvimavi, K., \& Twomlow, S. (2009). Socioeconomic and institutional factors influencing adoption of conservation farming by vulnerable households in Zimbabwe. Agricultural Systems, 101(1-2), 20-29. Available at: https://doi.org/10.1016/j.agsy.2009.02.002.

Msuya, E., Hisano, S., \& Nariu, T. (2008). An analysis of technical efficiency of smallholder maize farmers in Tanzania in the Globalization Era. Paper presented at the XII World Congress of Rural Sociology of the International Rural Sociology Association, Goyang, Korea 2008.

NEPAD. (2006). Contract farming offers fresh hope for Africa's declining agriculture. East Africa Policy Brief No. 2. Sida, World Agroforestry Centre, NEPAD Secretariat Agriculture Unit, Midrand, South Africa.

Otsuki, T. (2010). Estimating agroforestry's effect on productivity in Kenya: An application of a treatment effects model. OSIPP Discussion Paper, No. DP-2010-E-001.

Pattanayak, S. K., \& Mercer, D. E. (2002). Indexing soil conservation: Farmer perceptions of agroforestry benefits. Journal of Sustainable Forestry, 15(2), 63-85. Available at: https://doi.org/10.1300/j091v15no2_03.

Pitt, M. M., \& Khandker, S. R. (1998). The impact of group-based credit programs on poor households in Bangladesh: Does the gender of participants matter? Journal of Political Economy, 106(5), 958-996. Available at: https://doi.org/10.1086/250037.

Prowse, M. (2012). Contract farming in developing countries: A review. Paris, France: French Development Agency to know. 
Rapsomanikis, G. (2015). The economic lives of smallholder farmers, An analysis based on household data from nine countries: Food and Agriculture Organization of the United Nations Rome.

Rosenbaum, P. R., \& Rubin, D. B. (1983). The central role of the propensity score in observational studies for causal effects. Biometrika, $70(1), 41-55$. Available at: https://doi.org/10.1093/biomet/70.1.41.

Rural Livelihood Development Company -RLDC. (2008). Cotton market development strategy for central Tanzania. Proposal to RLDC Board Submitted on 21.11.2008.

Saigenji, Y. (2010). Contract farming and its impact on production efficiency and rural household income in the Vietnamese tea sector. Dissertation Submitted in Fulfillment of the Requirements for the Degree "Doctor of Agricultural Sciences" (Dr. Sc. Agrarian./ Ph.d. in Agricultural Sciences) to the Faculty of Agricultural Sciences.

Songsak, S., \& Wiboonpoongse, A. (2008). Overview of contract farming in Thailand: Lessons learned. ADBI Discussion Paper No. 112. Tokyo: Asian Development Bank Institute.

TCB. (2010). Tanzania cotton board. Annual Report and Accounts for the Year Ending on 30th June 2010.

TCB. (2018). Tanzania cotton board. Annual Report and Accounts for the Year Ending on 30th June 2017.

Tiongco, M., Catelo, M. A., \& Lapar, M. L. (2007). Contract farming of swine in Southeast Asia as a response to changing market demand for quality and safety in pork. A Working Paper for Submission as IFPRI Discussion Paper Series.

URT. (2016). Agricultural sector development programme two (ASDP II): Government Programme Document May 2016 (pp. 42). Ministry of Agriculture and Livestock Development, United Republic of Tanzania.

Van Den Berg, J. (2013). Socio-economic factors affecting adoption of improved agricultural practices by small scale farmers in South Africa. African Journal of Agricultural Research, 8(35), 4490-4500. Available at: https://doi.org/10.5897/ajar12.1025.

Vermeulen, H., Kirsten, J., \& Sartorius, K. (2006). Engagement with farmers from agro-processing companies in South Africa. South Africa: Department of Agricultural Economics, Extension and Rural Development, University of Pretoria.

Wainaina, P. W., Okello, J. J., \& Nzuma, J. (2012). Impact of contract farming on smallholder poultry farmers' income in Kenya. Paper presented at the International Association of Agricultural Economists Triennial Conference, Iguaçu, Brazil, 18-24 August 2012.

Warning, M., \& Key, N. (2002). The social performance and distributional consequences of contract farming: An equilibrium analysis of the Arachide de Bouche program in Senegal. World Development, 30(2), 255-263.

Yadav, P., \& Marwah, C. (2015). The concept of productivity. International Journal of Engineering and Technical Research, 3(5), 192-196.

Views and opinions expressed in this article are the views and opinions of the author(s), International Journal of Social and Administrative Sciences shall not be responsible or answerable for any loss, damage or liability etc. caused in relation to/arising out of the use of the content. 